\title{
UTILIZATION OF SOME EGYPTIAN RAW MATERIALS IN ROCK WOOL INDUSTRY: THERMAL AND ACOUSTIC INSULATION
}

\author{
Farouk, M. ${ }^{{ }^{*}}$, Soltan, A. ${ }^{2}$, Farrag, A. ${ }^{2}$, El Kammar, A. ${ }^{3}$, Hamzawy, E. ${ }^{4}$ \\ 1 Glass Rock insulation company, Cairo, Egypt. \\ 2 Geology Department, Faculty of Science, Ain Shams University, Egypt. \\ 3 Geology Department, Faculty of Science, Cairo University, Egypt. \\ 4 National Research Center, Dokki, Egypt. \\ "Correspondence author. E-mail: Faroukageo@yahoo.com
}

\begin{abstract}
In the time of increasing the cost of energy, we try to use different grades or inexpensive basalt in rock wool production to reduce the cost and produce well-matched rock wool quality commodities. This work assesses the suitability of basalt from three localities in Egypt (Abu-Zaabal, El-Fayoum and Baharyia) to produce rock wool that intended for thermal and acoustic insulation of buildings, and industrial equipment. Dolostone from Gabal Ataqa was incorporated in the batch to facilitate melting of basalt. All raw samples and the produced rock wool were chemically characterized using XRF. In addition, the different properties of the obtained rock wool such as thermal, mechanical, acoustic and reaction to fire have been evaluated. The obtained results reveal that all rock wool characteristics are bracketed in the acceptable range for the thermal, mechanical, acoustic and reaction to fire properties. The thermal conductivity $(\mathrm{K})$ of all wool slabs are bracketed in the acceptable ranges of standard specifications.
\end{abstract}

Keywords: basalt, dolostone, rock wool, thermal insulation.

\section{INTRODUCTION}

Rock wool is used as thermal, fire and acoustic insulation in building and industrial applications. There are two commercially available types of wool fibres used in heat and sound insulation mainly based on basalt as raw batch, these are the short and long (continuous) fibres. The short fibres are those known as rock wool or basalt wool and mainly used in the formulation of insulation boards and blankets. The continuous fibres are characterized with higher tensile strength over the short ones allowing their use in the composites and reinforcement applications (Perevozchikova et al. 2014; Jamshaid and Mishra, 2015 and Elbakian et al., 2018).

The present study concerns the evaluation of different Egyptian basalts to produce rock wool applying the Cupola furnace technology. In such technology, the basalts should contain $\geq 46$ (wt.\%) $\mathrm{SiO}_{2}$ to fit well the mandatory processing operational conditions to obtain the glass network among the single fibre (Jamshaid and Mishra, 2015). Dolomite is the main additive component in the current work mix compositions to adjust the required content of alkaline earth oxides, mainly $\mathrm{Ca}$. High quality composition of dolomite facilitates the batch melting and consequently, decrease the melt viscosity and energy consumption and increase the melt flowability, productivity and the resultant fibre quality as the product.

\section{MATERIALS AND METHODOLOGY}

\section{Materials}

The collected Egyptian basalt samples are commercially available in Abu-Zaabal, El-Fayoum, Baharyia, while dolomite samples are obtained from Gabal Ataqa areas. The single collected basalt sample (Fig. 1)- from each area - were quartered and then mixed to represent three separate technological basalt samples. The technological basalt and dolomite samples were used to prepare three batch compositions as feeding raw meals to the Cupola furnace with foundry coke as fuel to produce basalt rock 
wool of short fibres on an industrial scale (Fig. 2). The pre-melting batches, the melted batches, i.e., cinders, in addition to the final products, i.e., wool fibres, are all characterized in detail.

Fig. 1: The localities of the collected basalt samples used in the present study

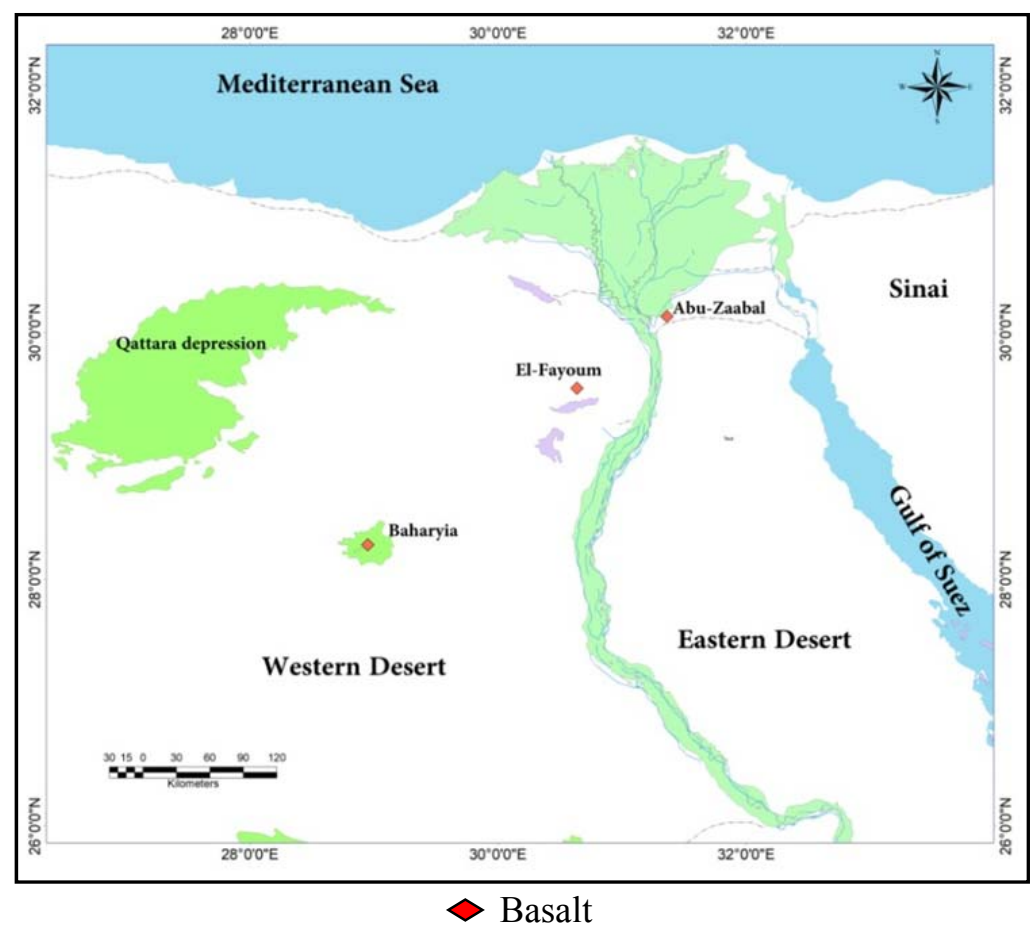

\section{Methodology}

The mixed raw materials had been charged to the Cupola furnace passed through different processes till preparation of wool slabs (Fig. 2 a-i). Moreover, both raw materials and the molten cinder samples picked from the "siphon exit" at the bottom side of the Cupola melting furnace (Fig. 2-a) were analyzed by XRF using a Philips PW2404 spectrometer at the central laboratories of the Egyptian Mineral Resources Authority. Measurements of the compressive stress, tensile stress and point load were conducted for rock wool slabs using the INSTRON 3300 series of mechanical testing systems supported with BLUHILL universal software. This is following EN 826, EN 12430 and EN 1607 respectively.

\section{RESULTS AND DISCUSSIONS}

\section{Basalt composition and moduli}

The predicted flowability behaviour of the raw basalt before mixing with any dolomite for batch composition is of critical importance in the rock wool plants. The basalt melt/cinder flowability is a function of its chemical composition and consequently mineral content. The flowability behaviour are determined by calculating different moduli based on the chemical composition of the raw basalt before dolomite mixing and the consequent furnace feeding. The calculated moduli of the basalt samples would predict the consistency of the melt and the easiness of its fiberization with minimum content of nonfiberized inclusions, i.e., shots (Angwafo et al., 1998; Trdic et al., 1999; Blagojevic et al., 2004; ASTM C1335-12, 2017 and Elbakian et al., 2018).

All the collected basalt samples exhibit basic composition with $\mathrm{CaO} / \mathrm{MgO}$ ratio $\geq 0.5$, proving their suitability for the wool industry applying either the one component scheme, i.e., the duplex method (Lebedeva., 2007) or the two-component scheme, i.e., the Cupola technology, as well $\left(\mathrm{STM}^{\circledR}, 2010\right.$ \& Perevozchikova et al. 2014) (Table. 1). When the $\mathrm{CaO} / \mathrm{MgO}$ ratio is $\leq 0.5$, i.e., increase of $\mathrm{MgO}$, the basalt rocks are not suitable for the wool production due to the higher melting temperature required for the industrial operation. In addition, the higher $\mathrm{MgO}$ content would initiate its separation form the melt as crystalline olivine which would minimize the wool quality. As well, iron and titanium would motivate the melt crystallization (Lebedeva, 2007 and Perevozchikova et al., 2014). The average $\mathrm{CaO} / \mathrm{MgO}$ ratio 


\section{Utilization of some Egyptian raw materials in rock wool industry}

recorded 0.96, 1.51 and 1.69 in Baharyia, Abu-Zaabal and El-Fayoum respectively. The best average $\mathrm{CaO} / \mathrm{MgO}$ ratio is recorded for El-Fayoum basalts (1.69, Table. 1) suggesting less predicted remnant nonmelted olivine in the melt during processing or in the fibre as end-product. The lower the remnant olivine in the basaltic melt, the higher is the melt consistency, fiberizability and the best is the fibre quality as well. The acidity modulus $\left(\mathrm{M}_{\mathrm{a}}\right)$ for the raw basalt samples is calculated to evaluate the quality of the basaltic melt. The calculated acidity modulus $\left(\mathrm{M}_{\mathrm{a}}\right)$ values would help in the prediction of the wool quality as a final product.

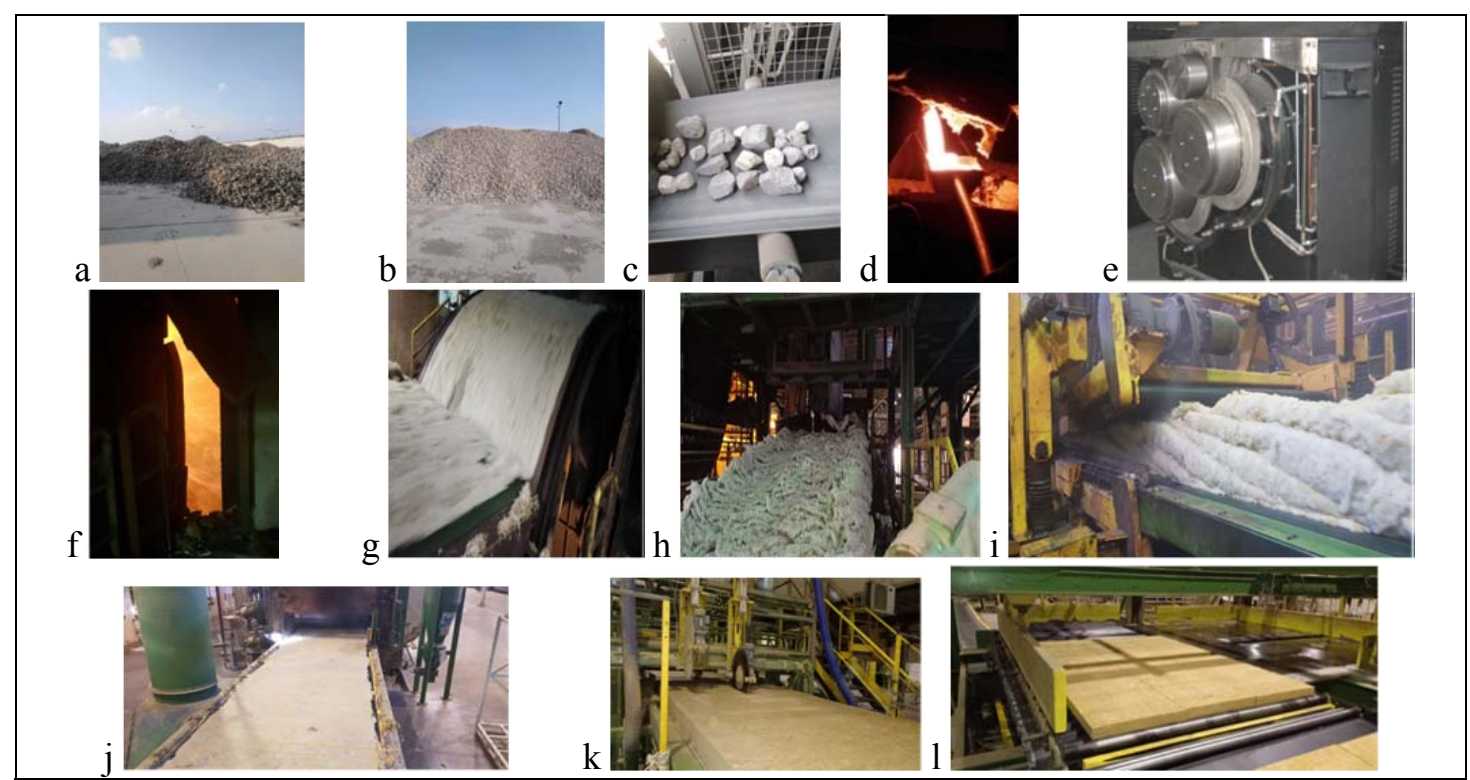

Fig. 2: The batch melting and fabrication process of wool slabs: a- The basalt raw material. b- The dolomite raw material. c- The charging of mixed basalt and dolomite in to Cupola furnace. d- The collection of batch cinder from Cupola furnace exit "Siphon". e- The fiberization process of molten cinders. f- The resultant hot fibers. g- The collection of hot fibres on drum sheet. h- The distribution of wool through pendulum left-right movement. i- The preparation of the required thicknesses and densities through crimping machine. $\mathrm{j}$ - The curing of wool to obtain slabs. k- The cutting process of slabs to the required dimensions. 1- The stacking of the wool slabs or boards.

The Ma is calculated according to the equation:

$\mathbf{M a}=\mathbf{m S i O}_{2}+\mathbf{m A l}_{2} \mathbf{O}_{3} / \mathbf{m C a O}+\mathbf{m M g O}$, where $\mathbf{m}$ : Mass content of oxides (wt. $\%$ )

$\mathrm{M}_{\mathrm{a}}$ typifies the molten composition and the raw material as well. If the $\mathrm{M}_{\mathrm{a}}$ of the raw basalt is $<1.8$, the produced fibres are expected to be brittle but have good insulation properties (Perevozchikova et al. 2014). However, the wool properties in terms of strength, corrosion, temperature resistance and thermal insulation would be better when $\mathrm{Ma}$ is $>1.8$, i.e., the higher the Ma of the raw basalt, the better quality is the wool fibre as a final product. The calculated Ma values for the collected basalt samples show that all samples meet the high-quality rock wool characteristics with $\mathrm{M}_{\mathrm{a}}>1.8$ (Table. 1).

The calculated average Ma moduli and the $\mathrm{CaO} / \mathrm{MgO}$ ratios of the raw basalt samples (Table.1) would encourage the use of the raw basalt as a main feed to produce wool fibre by the Cupola furnace applying the two-component technology. Each technological sample from the raw basalt of El-Fayoum, Bahariya and Abu-Zabal representing 73.47wt. \% from the total batch was mixed with $26.53 \mathrm{wt} . \%$ from dolomite as additive to formulate three feeding raw batches with utilizing coke as fuel source in Cupola furnace. The chemical analyses of the single and the technological samples are used for the accurate quantitative calculations of the potential minerals by applying the CIPW Norm method (Morse, 1980). 
Table 1: The chemical composition and the moduli of the collected basalt samples

\begin{tabular}{|c|c|c|c|c|c|c|c|c|c|c|c|c|c|c|c|c|}
\hline Locality & $\mathrm{SiO}_{2}$ & $\mathrm{TiO}_{2}$ & $\mathrm{Al}_{2} \mathrm{O}_{3}$ & $\mathrm{Fe}_{2} \mathrm{O}_{3}$ & $\mathrm{MnO}$ & $\mathrm{MgO}$ & $\mathrm{CaO}$ & $\mathrm{Na}_{2} \mathrm{O}$ & $\mathrm{K}_{2} \mathrm{O}$ & $\mathrm{P}_{2} \mathrm{O}_{5}$ & L.O.I & Total & $\mathrm{Ma}$ & $\begin{array}{c}\text { Avg. } \\
\mathrm{Ma}\end{array}$ & $\mathrm{CaO}: \mathrm{MgO}$ & $\begin{array}{c}\text { Avg. } \\
\mathrm{CaO}: \mathrm{MgO}\end{array}$ \\
\hline Abu-Zaabal & 48.94 & 2.34 & 14.18 & 12.65 & 0.17 & 6.81 & 9.53 & 2.93 & 0.83 & 0.29 & 1.24 & 99.91 & 3.86 & \multirow{4}{*}{3.99} & 1.40 & \multirow{4}{*}{1.51} \\
\hline Abu-Zaabal & 49.45 & 2.37 & 13.73 & 12.96 & 0.18 & 6.28 & 9.56 & 2.68 & 0.81 & 0.31 & 1.56 & 99.89 & 3.99 & & 1.52 & \\
\hline Abu-Zaabal & 50.00 & 2.38 & 13.79 & 12.75 & 0.17 & 5.78 & 9.58 & 3.00 & 1.16 & 0.29 & 0.95 & 99.85 & 4.15 & & 1.66 & \\
\hline Abu-Zaabal & 50.50 & 2.16 & 14.46 & 12.32 & 0.16 & 5.69 & 10.07 & 2.07 & 1.01 & 0.31 & 0.95 & 99.70 & 4.12 & & 1.77 & \\
\hline El-Fayoum & 50.50 & 2.76 & 14.40 & 12.81 & 0.16 & 5.60 & 9.40 & 2.70 & 1.04 & 0.32 & 0.30 & 99.99 & 4.33 & \multirow{4}{*}{4.29} & 1.68 & \multirow{4}{*}{1.69} \\
\hline El-Fayoum & 50.60 & 2.76 & 14.40 & 12.79 & 0.16 & 5.67 & 9.60 & 2.30 & 1.05 & 0.30 & 0.33 & 99.96 & 4.26 & & 1.69 & \\
\hline El-Fayoum & 50.40 & 2.76 & 14.20 & 12.70 & 0.14 & 5.60 & 9.40 & 2.60 & 1.10 & 0.29 & 0.80 & 99.99 & 4.31 & & 1.68 & \\
\hline El-Fayoum & 50.51 & 2.76 & 14.30 & 12.81 & 0.18 & 5.25 & 9.50 & 2.66 & 1.01 & 0.32 & 0.70 & 100.00 & 4.39 & & 1.81 & \\
\hline Baharyia & 48.95 & 1.71 & 12.11 & 12.85 & 0.14 & 10.98 & 7.55 & 2.83 & 1.23 & 0.31 & 1.10 & 99.76 & 3.30 & \multirow{4}{*}{3.63} & 0.69 & \multirow{4}{*}{0.96} \\
\hline Baharyia & 49.27 & 1.88 & 13.73 & 11.14 & 0.13 & 8.34 & 8.91 & 3.10 & 1.18 & 0.47 & 1.25 & 99.40 & 3.65 & & 1.07 & \\
\hline Baharyia & 48.89 & 1.87 & 13.84 & 10.89 & 0.15 & 7.85 & 8.92 & 3.01 & 1.18 & 0.46 & 1.86 & 98.92 & 3.74 & & 1.14 & \\
\hline Baharyia & 49.13 & 1.86 & 14.55 & 10.70 & 0.12 & 8.57 & 7.97 & 2.92 & 1.36 & 0.48 & 2.03 & 99.69 & 3.85 & & 0.93 & \\
\hline
\end{tabular}


The CIPW norms show that both mineral/crystalline average values for Abu-Zaabal, El-Fayoum and Baharyia are $85.97,86.75$ and $86.51 \mathrm{wt} . \%$ respectively, and the glass/amorphous values for these rocks are $14.03,13.25$ and $13.49 \mathrm{wt} . \%$, respectively. The expected CIPW norm crystalline phases are mainly consist of plagioclases (Albite+Anorthite) in Abu-Zaabal, El-Fayoum and Baharyia with values of 45.46, 46.42 and $45.12 \mathrm{wt} . \%$, respectively, and the CIPW norm of Mg-bearing minerals of Abu-Zaabal, El-Fayoum and Baharyia samples are composed of pyroxene (diopside (Di) and hypersthene (Hy) with values of 22.35, 19.15 and $27.55 \mathrm{wt} . \%$, respectively. The XRD patterns (Fig. 3) proved that Abu-Zaabal, El- Fayoum and Baharyia samples are mineralogically composed of plagioclase- anorthite $\left(\mathrm{Al}_{(1.91)} \mathrm{Ca}_{(0.716)} \mathrm{Mn}_{(0.196)} \mathrm{Na}_{(0.045)} \mathrm{Si}_{(2.089)} \mathrm{O}_{8}\right)$ and plagioclase- labradorite$\left(\mathrm{Al}_{(1.67)} \mathrm{Ca}_{(0.67)} \mathrm{Na}_{(0.33)} \mathrm{Si}_{(2.33)} \mathrm{O}_{8}\right)$, which are bracketed in the range (45.20-74.50wt.\%). The plagioclases are associated mainly with the Mg-rich minerals enstatite $\left(\mathrm{MgSiO}_{3}\right),(37.6 \mathrm{wt}$. \% in Abu-Zaabal only); diopside $\left(\mathrm{CaMgSi}_{2} \mathrm{O}_{6}\right),\left(11.6-17.2\right.$ wt. \%) and augite $\left((\mathrm{CaFe})_{(0.25)} \mathrm{Mg}_{(0.74)} \mathrm{Si}_{2} \mathrm{O}_{6}\right),(9.9,21.8$ wt. \% in Baharyia and El-Fayoum respectively).

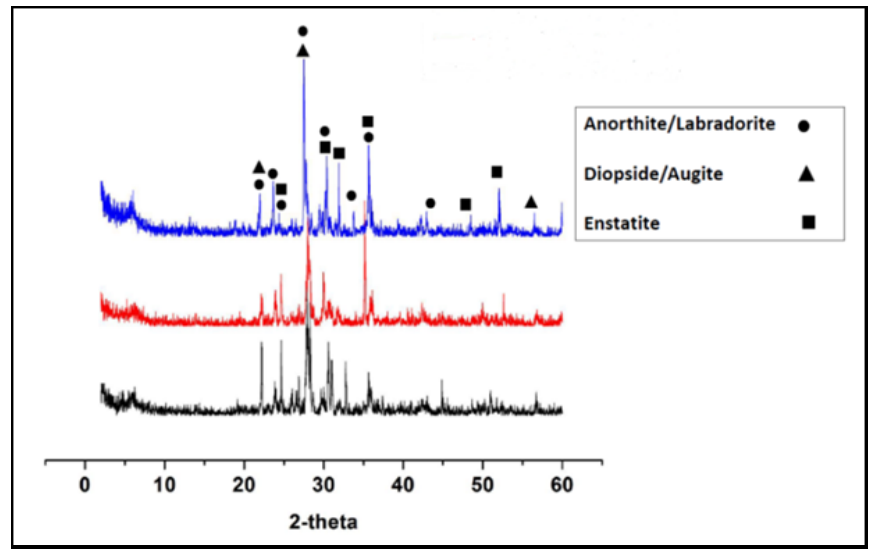

Fig. 3: The XRD patterns of the basalt samples

Basalt Baharyia

Basalt El-Fayoum

Basalt Abu-Zaabal

\section{CINDERS COMPOSITION AND MODULI}

After the complete melting of each batch, a cinder, i.e., melt, sample was picked-up using a steel spoon from a microscopic outlet located at the side of the Cupola furnace known as "Siphon" (Fig. 2d). The three molten cinders were chemically analysed using XRF (Table 2). The XRF data of the three cinder samples shows the variation of the different oxide contents in the cinders (Table 3 ). $\mathrm{SiO}_{2}, \mathrm{Al}_{2} \mathrm{O}_{3}, \mathrm{Fe}_{2} \mathrm{O}_{3}, \mathrm{MgO}$ and $\mathrm{CaO}$ values range between (44.82-46.29); (13.4-14.08); (4.34-6.62); (10.68-11.68) and (18.5 to $18.76 \mathrm{wt} . \%)$, respectively. The XRF values of the three cinders are compared with the commercial values of cinder composition (Brown and Harrison, 2012) (Table 2). The oxide contents of the present study cinders are falling in the acceptable range values for $\mathrm{SiO}_{2}$, $\mathrm{Al}_{2} \mathrm{O}_{3}, \mathrm{Fe}_{2} \mathrm{O}_{3}, \mathrm{MgO}$ and $\mathrm{CaO}$ as deriving material for wool production (Brown and Harrison, 2012). The calculated $\mathrm{M}_{\mathrm{a}}$ values of the three cinders suggest high-quality basalt wool with $\mathrm{M}_{\mathrm{a}}>1.8$ in all samples. El-Fayoum cinder is showing the highest average $M_{a}$ value (2.04) whereas Baharyia is showing the lowest (1.94) (Table 2). The average $\mathrm{CaO} / \mathrm{MgO}$ ratio in all cinder samples are $>0.5$ (1.76, 1.72 and 1.58) in Abu-Zaabal, El-Fayoum and Baharyia respectively (Table 2), suggesting consistent melting with high fiberizing ability and fibre quality (Lebedeva, 2007; STM ${ }^{\circledR}, 2010$; and Perevozchikova et al. 2014).

Table 2: The chemical composition of the collected cinders.

\begin{tabular}{|l|c|c|c|c|c|c|c|c|c|c|c|c|}
\hline \multicolumn{1}{|c|}{ Sample name } & $\mathrm{SiO}_{2}$ & $\mathrm{TiO}_{2}$ & $\mathrm{Al}_{2} \mathrm{O}_{3}$ & $\mathrm{Fe}_{2} \mathrm{O}_{3}$ & $\mathrm{MnO}$ & $\mathrm{MgO}$ & $\mathrm{CaO}$ & $\mathrm{Na}_{2} \mathrm{O}$ & $\mathrm{K}_{2} \mathrm{O}$ & $\mathrm{P}_{2} \mathrm{O}_{5}$ & $\mathrm{Ma}$ & $\mathrm{CaO}: \mathrm{MgO}$ \\
\hline Abu-Zaabal batch cinder & 44.82 & 2.77 & 13.64 & 6.20 & 0.15 & 10.68 & 18.76 & 2.15 & 0.77 & 0.06 & 1.99 & 1.76 \\
\hline El-Fayoum batch cinder & 46.29 & 2.50 & 14.08 & 4.34 & 0.12 & 10.91 & 18.72 & 2.16 & 0.80 & 0.08 & 2.04 & 1.72 \\
\hline Baharyia batch cinder & 45.20 & 2.24 & 13.40 & 6.62 & 0.17 & 11.68 & 18.50 & 1.21 & 0.73 & 0.25 & 1.94 & 1.58 \\
\hline $\begin{array}{l}\text { Commercial cinder (Brown } \\
\text { and Harrison, 2012) }\end{array}$ & $\begin{array}{c}43- \\
50\end{array}$ & - & $6-15$ & $3-8$ & - & $6-16$ & $10-25$ & $1-3.5$ & $0.5-2.00$ & $0-0.50$ & - & $>1.5$ \\
\hline
\end{tabular}

\section{Rock wool charachterization}

\section{Mechanical properties}

The samples tested for compressive stress, at $10 \%$ deformation, have the same density $\left(100 \mathrm{~kg} / \mathrm{m}^{3}\right)$, i.e., d100 samples (Table 3). The calculated compressive stress of the (d100) samples are shown in 
(Table 3). The average compressive stress values at $10 \%$ deformation are $10.47,13.35$ and $14.29 \mathrm{KPa}$ at $104.73,133.52$ and $142.88 \mathrm{~N}$, for Baharyia, Abu-Zaabal and El-Fayoum insulating boards, respectively (Table 3). All boards compressive stress values are $\geq 0.5,2.4 \mathrm{KPa}$ which is the acceptable value of the European and American standards EN 13162 and ASTM C612-14. All the measured point load values for El-Fayoum, Abu-Zaabal and Bahariya samples are agreeing fairly with EN 13162 which typifies the (F5) accepted value to be $\geq 50 \mathrm{~N}$. El-Fayoum wool board shows the maximum point load at $(140 \mathrm{~N})$ with the least value recorded for the Baharyia $(100 \mathrm{~N})$, whereas Abu-Zaabal is showing the medium value $(130 \mathrm{~N})$ (Table 3). The obtained results of tensile strength recorded 3, 2.5, $2 \mathrm{KPa}$ in El-Fayoum, Abu-Zaabal and Baharyia board samples of $100 \mathrm{~kg} / \mathrm{m}^{3}$, respectively (Table 3). Additionally, El-Fayoum board is of the least shot contents (13wt.\%), determined according to (ASTM C1335) which could be considered as harmful-microstructure bodies to interrupt the continuity of the single fibre orientation. Shots are points of weakness for the mechanical characteristics in general, therefore, the lower the shots content (Table 3), the better is the mechanical characteristics of the board (Gnip et al., 2009; Hild et al., 2009; Gnip et al., 2010; Steponaitis and Vejelis, 2010 and Steponaitis et al., 2012).

Table 3: The mechanical properties of the prepared slabs.

\begin{tabular}{|l|c|c|c|c|c|c|c|}
\hline Specimen/Standard & $\begin{array}{c}\text { Density } \\
\mathrm{Kg} / \mathrm{m}^{3 "}\end{array}$ & $\begin{array}{c}\text { Thickness } \\
(\mathrm{mm})\end{array}$ & $\sigma 10(\mathrm{Kpa})$ & $\begin{array}{c}\text { Load at maximum } \\
\text { compressive stress }\end{array}$ & $\begin{array}{c}\text { Behaviour under } \\
\text { point load (N) }\end{array}$ & $\begin{array}{c}\text { Tensile strength } \\
\text { "TR" (Kpa) }\end{array}$ & $\begin{array}{c}\text { Shot content } \\
(\mathrm{wt} . \%)\end{array}$ \\
\hline El-Fayoum (d100) & 100 & 50 & 14.29 & 142.88 & 140 & 3 & 13 \\
\hline Abu-Zaabal (d100) & 100 & 50 & 13.35 & 133.52 & 130 & 2.5 & 14 \\
\hline Baharyia (d100) & 100 & 50 & 10.47 & 104.72 & 100 & 2 & 16 \\
\hline $\begin{array}{l}\text { EN 13162:2012 } \\
\text { specs }\end{array}$ & - & - & $\geq 0.5$ & - & $\geq 50$ & $\geq 1$ & - \\
\hline $\begin{array}{l}\text { ASTM C612-14 } \\
\text { specs }\end{array}$ & - & - & $\geq 2.4$ & - & - & - & $\leq 25$ \\
\hline
\end{tabular}

\section{Thermal properties}

The K-values of the prepared samples range from (35.35 to $36.00 \mathrm{~mW} / \mathrm{mK}$ ) for all samples (Table 4). These results fall in the acceptable K-values for the wool boards according to EN 13162, EN 14303, ASTM-C612-14 and GB/T 25975 ( $\leq 60, \leq 65, \leq 36$ and $\leq 40$, respectively). R-values of the present wool board samples, bracketed between 1.389 and $1.414 \mathrm{~m}^{2} \mathrm{~K} / \mathrm{W}$, are much better than the limitations of the warm climate regions such like the Gulf countries cooperative council (GCCC, $1984) \geq 1.35 \mathrm{~m}^{2} \mathrm{~K} / \mathrm{W}$ in wall applications (Al-Homoud, 2004) (Table. 4).

Table 4: The thermal properties of the prepared slabs

\begin{tabular}{|c|c|c|c|c|}
\hline Sample code and standards & $\begin{array}{c}\text { Density } \\
\text { "Kg/m }\end{array}$ & $\begin{array}{c}\text { K-value } \\
(\mathrm{mW} . \mathrm{mK})\end{array}$ & $\begin{array}{c}\text { Thickness } \\
(\mathrm{mm})\end{array}$ & $\begin{array}{c}\text { R-vlaue } \\
\left(\mathrm{m}^{2} . \mathrm{K} / \mathrm{W}\right)\end{array}$ \\
\hline Abu-Zaabal (d100) & 100.00 & 35.39 & 50.00 & 1.412 \\
\hline El-Fayoum (d100) & 100.00 & 35.35 & 50.00 & 1.414 \\
\hline Baharyia (d100) & 100.00 & 36.00 & 50.00 & 1.389 \\
\hline EN 13162:2012 specs & - & $\leq 60$ & - & $\geq 0.6$ \\
\hline EN 14303:2015 specs & - & $\leq 65$ & - & - \\
\hline ASTM-C612-14 specs & - & $\leq 36$ & - & - \\
\hline GB/T 25975-2010 specs & - & $\leq 40$ & - & $\geq 1.35$ for walls \\
\hline GCCC specs* & - & - & - & \\
\hline
\end{tabular}

\section{Acoustic properties}

The NRC values of all samples found to have extremely absorbing characteristics in accordance with ASTM C423-08 and EN ISO 11654 (Table. 5) where the insulation boards are said to be categorized as class A (NRC $\geq 0.75 \& \alpha \mathrm{w}$ from 0.9 to 1 ). All board samples in this study achieved A class with equal NRC values of Abu-Zaabal (d100) and El-Fayoum (d70) specimens (1.05) whereas Baharyia (d50) insulating board recorded $0.95 \mathrm{NRC}$ value and $(\alpha \mathrm{w})$ of 1 in all specimens. In addition, all board samples have similar behavior of sound absorption coefficient $(\alpha \mathrm{s})$ where the values increase from 0.13 to $1.07,0.1$ to 1.15 and 0.14 to 1.13 with frequency from $100-5000 \mathrm{~Hz}$ in Abu-Zaabal (d100), El-Fayoum (d70) and Baharyia (d50), respectively (Table. 5). This is attributed to the very high apparent porosity recorded for Abu-Zaabal (d100), El-Fayoum (d70) and Baharyia (d50) insulating boards $(95.28,95.56$ and $95.58 \%$, respectively) that determined by Helium porosimeter. 
Table 5: The measured acoustic characteristics of the prepared samples of Abu-Zabaal-(d100), El-Fayoum-(d70) and Baharyia-(d50)

\begin{tabular}{|c|c|c|c|c|c|c|c|c|c|c|c|c|c|c|c|c|c|c|}
\hline \multirow{3}{*}{$\begin{array}{c}\text { Frequency } \\
(\mathrm{Hz})\end{array}$} & \multicolumn{6}{|c|}{ Abu-Zaabal (d100) } & \multicolumn{6}{|c|}{ El-Fayoum (d70) } & \multicolumn{6}{|c|}{ Baharyia (d50) } \\
\hline & \multirow[t]{2}{*}{$\alpha \mathrm{s}^{*}$} & \multirow[t]{2}{*}{$\alpha p^{*}$} & \multicolumn{2}{|c|}{$\begin{array}{c}\text { EN ISO } \\
11654: 97 \\
\end{array}$} & \multicolumn{2}{|c|}{$\begin{array}{c}\text { ASTM C423- } \\
08 \\
\end{array}$} & \multirow[t]{2}{*}{$\alpha \mathrm{s}$} & \multirow[t]{2}{*}{$\alpha p$} & \multicolumn{2}{|c|}{$\begin{array}{c}\text { EN ISO } \\
11654: 97\end{array}$} & \multicolumn{2}{|c|}{$\begin{array}{c}\text { ASTM } \\
\text { C423-08 } \\
\end{array}$} & \multirow[t]{2}{*}{$\alpha \mathrm{s}$} & \multirow[t]{2}{*}{$\alpha p$} & \multicolumn{2}{|c|}{$\begin{array}{c}\text { EN ISO } \\
11654: 97 \\
\end{array}$} & \multicolumn{2}{|c|}{$\begin{array}{c}\text { ASTM C423- } \\
08\end{array}$} \\
\hline & & & $\alpha \mathrm{w}^{*}$ & Class & NRC* & SAA* & & & $\alpha \mathrm{w}$ & Class & NRC & SAA & & & $\alpha \mathrm{w}$ & Class & NRC & SAA \\
\hline 125 & 0.22 & 0.25 & \multirow{15}{*}{1} & \multirow{15}{*}{ A } & \multirow{15}{*}{1.05} & \multirow{15}{*}{1.01} & 0.20 & 0.20 & \multirow{15}{*}{1} & \multirow{15}{*}{$\mathrm{A}$} & \multirow{15}{*}{1.05} & \multirow{15}{*}{1.02} & 0.2 & 0.2 & \multirow{15}{*}{1} & \multirow{15}{*}{$\mathrm{A}$} & \multirow{15}{*}{0.95} & \multirow{15}{*}{0.93} \\
\hline 160 & 0.33 & & & & & & 0.37 & & & & & & 0.31 & & & & & \\
\hline 200 & 0.57 & & & & & & 0.55 & & & & & & 0.45 & & & & & \\
\hline 250 & 0.90 & 0.85 & & & & & 0.87 & 0.80 & & & & & 0.72 & 0.7 & & & & \\
\hline 400 & 1.13 & & & & & & 1.05 & & & & & & 0.97 & & & & & \\
\hline 500 & 1.07 & 1.00 & & & & & 1.11 & 1.00 & & & & & 1.00 & 1.00 & & & & \\
\hline 630 & 1.12 & & & & & & 1.15 & & & & & & 1.07 & & & & & \\
\hline 800 & 1.10 & & & & & & 1.12 & & & & & & 1.06 & & & & & \\
\hline 1000 & 1.07 & 1.00 & & & & & 1.1 & 1.00 & & & & & 1.03 & 1.00 & & & & \\
\hline 1250 & 1.04 & & & & & & 1.06 & & & & & & 1.00 & & & & & \\
\hline 1600 & 1.05 & & & & & & 1.04 & & & & & & 1.02 & & & & & \\
\hline 2000 & 1.06 & 1.00 & & & & & 1.07 & 1.00 & & & & & 1.00 & 1.00 & & & & \\
\hline 3150 & 1.04 & & & & & & 1.02 & & & & & & 1.00 & & & & & \\
\hline 4000 & 1.02 & 1.00 & & & & & 1.06 & 1.00 & & & & & 1.03 & 1.00 & & & & \\
\hline 5000 & 0.99 & & & & & & 1.01 & & & & & & 1.05 & & & & & \\
\hline
\end{tabular}

- $\alpha \mathrm{S}^{*}$ - alpha: The sound absorption coefficient represents the amount of sound energy absorbed upon striking a surface (Cavanaugh, 2009; António, 2011 and Rahimabady et al., 2017).

- $\alpha p^{*}$ : Octave band values of Practical Sound Absorption Coefficient are calculated from the one-third octave results.

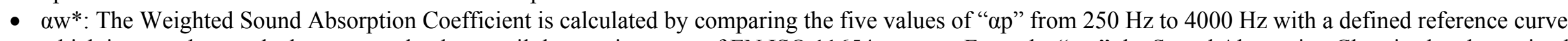
which is moved towards the measured values until the requirements of EN ISO 11654 are met. From the " $\alpha w$ " the Sound Absorption Class is also determined.

- NRC*: The noise reduction coefficient calculated from average 4 values of sound absorption coefficient " $\alpha$ s" at frequencies of 250, 500, 1000 and $2000 \mathrm{~Hz}$ then rounded to 0.05 . Since it was recommended to check material behavior at wider frequency range so the measurements done till $5000 \mathrm{~Hz}$ (Cavanaugh, 2009 ;

António, 2011).Moreover, it has scale from 0-1, the "NRC" of " 0 " value indicates perfect reflection; while of " 1 " value indicates perfect absorption

- SAA*: The Sound Absorption Average is calculated from the twelve ( $\alpha$ s) results from $200 \mathrm{~Hz}$ to $2500 \mathrm{~Hz}$, rounded to 0.01, both in accordance with ASTM C423-08. 


\section{Reaction to fire properties}

The fire performance parameters measured for El-Fayoum, Abu-Zaabal and Baharyia (Table. 6) insulating boards prove that all of them can be used as fire resistant insulating boards as guard for steel structures acting as a fire barrier preventing the spread of fire. The obtained results had been compared to EN 13501-1 and found that the reaction to fire characteristics of the three samples belong to the European A1 fire behaviour, which is the best and highest classification of fire reaction, and class A compared to ASTM E84-19b.

The flame spread index "FSI" and smoke developed index "SDI" recorded (0), reflecting high heat resistance of the wool boards under study. This could be related to the board samples high ( $\mathrm{Fe})$ content $(5.9,6.97,11.02 \mathrm{wt} . \%$, respectively) in El-Fayoum, Abu-Zaabal and Baharyia, respectively determined by EDS analysis (Talbot et al., 2000 and Deák and Czigány, 2009). Since EN 15715 declared that neither thickness nor density has influence on the reaction to fire characteristics, any produced wool thickness or density of El-Fayoum, Abu-Zaabal and Baharyia will attain class A1 reaction to fire characteristics with the same prescribed batches in this study.

Table 6: The values of the reaction to fire according to EN 13501-1:2018 and ASTM E84-19b.

\begin{tabular}{|c|c|c|c|c|c|c|}
\hline \multirow{3}{*}{ Sample code } & PCS (MJ $/ \mathrm{kg})$ & \multicolumn{2}{c|}{$\Delta \mathrm{T}\left({ }^{\circ} \mathrm{C}\right)$} & $\Delta \mathrm{m}(\%)$ & $\mathrm{Tf}(\mathrm{s})$ & \multicolumn{2}{c|}{ FSI } & SDI \\
\cline { 2 - 7 } & EN ISO 1716:2018 specs & \multicolumn{2}{|c|}{ EN ISO $1182: 2010$ specs } & \multicolumn{2}{c|}{ ASTM E84 specs } \\
\cline { 2 - 7 } & $\leq 2$ & $\leq 30$ & $\leq 50$ & 0 & $\leq 25$ & $\leq 450$ \\
\hline Abu-Zaabal (d100) & 0.32 & 10.00 & 1.70 & 0.00 & 0.00 & 0.00 \\
\hline El-Fayoum (d100) & 0.34 & 7.00 & 1.10 & 0.00 & 0.00 & 0.00 \\
\hline Baharyia (d100) & 0.33 & 9.00 & 1.60 & 0.00 & 0.00 & 0.00 \\
\hline
\end{tabular}

\section{CONCLUSIONS}

The calculated acidity moduli $(\mathrm{Ma})$ and the $\mathrm{CaO} / \mathrm{MgO}$ ratios of the raw basalt samples would encourage the use of the raw basalt as a main feed to produce rock wool fibre by the Cupola furnace applying the two-component technology. The calculated $\mathrm{M}_{\mathrm{a}}$ values of the three cinders suggest highquality basalt wool with $\mathrm{M}_{\mathrm{a}}>1.8$ in all samples. El-Fayoum cinder is showing the highest average $\mathrm{M}_{\mathrm{a}}$ value (2.04), whereas Baharyia is showing the lowest (1.94). This is attributed to El-Fayoum lowest concentration of Mg-bearing minerals (enstatite, diopside and augite) and consequent existence of the Ca-deriving minerals (anorthite- and labradorite-plagioclase) as confirmed by XRD (25.50 and 74.50, respectively) and CIPW (22.07 and 53.51, respectively).The resultant slab wool of Abu-Zaabal, ElFayoum and Baharyia were subjected for mechanical, thermal, acoustic and fire resistance characterization. The results show a good matching with the American and the European norms.

\section{ACKNOWLEDGEMENTS}

The authors are grateful for GlassRock Insulation Co., for providing the required industrial scale for this study.

\section{REFERENCES}

Al-Homoud, M. (2004): The effectiveness of thermal insulation in different types of buildings in hot climates. J.Thermal Env. and BLDG. SCI., 27, 235-247.

Angwafo, A. W, Bullen, P. R, and Philpott, D. R. (1998): Proceedings of FEDSM'98, ASME Fluids Engineering. Division Summer Meeting, Washington.

António, J. (2011): Acoustic behaviour of fibrous materials. Fibrous and Composite Materials for Civil Engineering Applications, 306-324.

ASTM C1335-12. (2017): American Society for Testing and Materials: Standard Test Method for Measuring Non-Fibrous Content of Man-Made Rock and Slag Mineral Fiber Insulation, 1-4.

ASTM C177-19. (2019): American Society for Testing and Materials: Standard Test Method for Steady-State Heat Flux Measurements and Thermal Transmission Properties by Means of the Guarded-Hot-Plate Apparatus, 1-23.

ASTM C423-08. (2008): American Society for Testing and Materials: Standard Test Method for Sound Absorption and Sound Absorption Coefficients by the Reverberation Room Method, 1-11.

ASTM C612-14. (2019): American Society for Testing and Materials: Standard Specification for Mineral Fiber Block and Board Thermal Insulation, 1-5. 
ASTM E84-19b. (2019): American Society for Testing and Materials: Standard Test Method for Surface Burning Characteristics of Building Materials, 1-26.

Blagojevic, B. Širok, B. and Štremfelj, B. (2004): Simulation of the effect of melt composition on mineral wool fiber thickness. Ceramics -Silikáty 48, 128-134.

Brown, R.C. and Harrison, P.T.C. (2012): Alkaline earth silicate wools-A new generation of high temperature insulation. Regulatory toxicity and pharmacology 64, 296-304.

Cavanaugh, W. J, Tocci, G. C, Wilkes, J. A. (2009): Architectural Acoustics, Principles and Practice. Chichester, Wiley \& Sons, 352p.

Deák, T. and Czigány, T. (2009): Chemical Composition and Mechanical Properties of Basalt and Glass Fibers: A Comparison, Textile Research J.ournal, 79(7), 645-651.

Elbakian, A., Sentyakov, B., Božek, P., Kuric, I., and Sentyakov, K. (2018): Automated Separation of Basalt Fiber and Other Earth Resources by the Means of Acoustic Vibrations. Acta Montanistica Slovaca , 23(3), 271-281

EN 12430. (2013): European standard: Thermal insulating products for building applications Determination of behaviour under point load, 1-12.

EN 12667. (2001): European standard: Thermal performance of building materials and products Determination of thermal resistance by means of guarded hot plate and heat flow meter methods Products of high and medium thermal resistance, 1-54.

EN 13162. (2012): European standard: Thermal insulation products for buildings - Factory made mineral wool (MW) products - Specification, 1-47.

EN 13501-1. (2018): European standard: Fire classification of construction products and building elements - Part 1: Classification using data from reaction to fire tests, 1-55.

EN 14303. (2015): European standard: Thermal insulation products for building equipment and industrial installations - Factory made mineral wool (MW) products-Specification, 38.

EN 15715. (2009): European standard: Thermal insulation products. Instructions for mounting and fixing for reaction to fire testing. Factory made products, 1-98.

EN 1607. (2013): European standard: Thermal insulating products for building applications Determination of tensile strength perpendicular to faces, 1-10.

EN 1716. (2018): European standard: Reaction to fire tests for products-Determination of the gross heat of combustion (calorific value), 1-30.

EN 826. (2013). European standard: Thermal insulating products for building applications Determination of compression behavior, 1-13.

EN ISO 11654. (1997): European standard: Acoustics-Sound absorbers for use in buildings- Rating of sound absorption, $1-7$.

EN ISO 1182. (2010): European standard: Reaction to fire tests for products-Non-combustibility test, $1-32$.

EN ISO 354. (2003): European standard: Acoustics-Measurement of sound absorption in a reverberation room, 1-21.

GB/T 25975. (2010): Rock Wool Products For Exterior Insulation And Finish Systems (EIFS) (TEXT OF DOCUMENT IS IN CHINESE), 1-3.

GCCC. (1984): Gulf Countries Cooperative Council, Gulf Countries Electric Energy Conservation Committee. Thermal Insulation Regulations, First Meeting of Gulf Ministers of Electricity, Doha, Qatar, Section II, Item 2, 30-31.

Gnip, I., Vaitkus, S., Keršulis, V., and Ve jelis, S. (2009): Predicting the deformability of mineral wool slabs under constant compressive stress. Construction and Building Materials 23, 1928-1934.

Gnip, I, Ve jelis, S, Keršulis, V, Vaitkus, S. (2010): Strength and deformability of mineral wool slabs under short-term compressive, tensile and shear loads, Construction and Building Materials, 24, 2124-2134.

Hild, F., Maire, E., Roux, S., and Witz, J. F. (2009): Three-dimensional analysis of a compression test on stone wool. Acta Materialia, 57, 3310-3320.

Jamshaid, H. and Mishra, R. (2015): A green material from rock: basalt fiber-a review. The Journal of the Textile Institute, 07(7), 923-937.

Lebedeva, G. A. (2007): Study of the technological properties of Karelian rocks as raw material for production of mineral wool. Glass and Ceramics, 64, 360-362.

Morse, S. A. (1980): Basalts and phase diagrams. New York, Springer-Verlag, 943p. 
Perevozchikova, B. V., Pisciottab, A, Osovetskya, B. M., Menshikova, E. A., and Kazymov K. P. (2014): Quality evaluation of the Kuluevskaya basalt outcrop for the production of mineral fiber, Southern Urals, Russia. Energy Procedia, 59, 309-314.

Rahimabady, M., Statharas, E. C., Yao, K., Mirshekarloo, M. S., Chen, S. T, and Tay, F. E. H. (2017): Hybrid local piezoelectric and conductive functions for high performance airborne sound absorption, American inst. of Physics. Appl. Phys. Lett. 111, 241601.

Steponaitis, L, Vè jelis, S., and Vaitkus, S. (2012): Analysis of Structure and Deformation Mechanisms of Mineral Wool Slabs Under Compression. Materials Science (Medžiagotyra), 18, 192-196.

Steponaitis, L., and Vè jelis, S. (2010): Strength and deformability of mineral wool slabs under shortterm cyclic compression. Statybinès konstrukcijos ir technologijos, 2, 86-92.

$\mathrm{STM}^{\circledR}$. (2010): Hand Book of Rock wool production line technology, STM ${ }^{\circledR}$ technology, Italy, 1-93.

Talbot, H., Lee, T., Jeulin, D., Hanton, D., and Hobbs, L.W. (2000): Image analysis of insulation mineral fibres, Journal of Microscopy, 200, 251-268.

Trdic, F, Širok, B, Bullen, P. R, and Philpott, D. R. (1999): Monitoring mineral wool production using real-time machine vision. Real Time Imaging, 5(2), 125-140. 


\section{استخدامات بعض الخامات المصرية في صناعة الصوف الصخري: للعزل الصوتي والحراري}

محمد فاروق حسن' وعبد المنعم محمد سلطان وعلي فراج عثمان ' وأحمد عبد العزيز الكمار 'وعصمت محمود حمزاوي؛ ا شركة جلاس روك للعزل ، ب قسم الجيولوجيا، كلية العلوم ، جامعة عين شمس ، r قسم الجيولوجيا، كلية العلوم، جامعة القاهرة ، ع قسم بحوث الزجاج، المركز القومى للبحوث ، الدقى ، القاهرة .

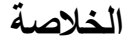

تهدف الورقة البحثية الى تقييم صخور البازلت في مناطق أبو زعبل والفيوم والبحرية من الناحية الجيوكيميائية والجيولوجية والدراسات التمعدنية لهذه الصخور في تحديد ملاءمتها لصناعة الصوف الصخرى لاستخدامه في العزل الحراري وعزل الصوت ومقاومة الحريق للمباني ـ كما تتاولت الورقة البحثية الربط بين هذه الخصائص وتأثيراتها على فئل عملية الانصهار وبالتالي خصائص المنتج النهائي وذلك عن طريق دراسة تفصيلية باستخدام تقنيات حيود الأثعة السينية والفلوريسينية الطيفية والمجهر المستقطب ـ بالإضافة الى استخدام صخور البازلت سالفة الذكر مع صخر الدولوميت كمادة صهارة من -جبل عناقة بمنطقة السويس- في خلطات على المقياس الصناعي لإنتاج ألواح الصوف الصخري وتقييم المنتج النهائي كيميائيا وفيزيائيا باستخدام الأشعة الفلوريسينية الطيفية، قياس الموصلية الحرارية، قياس الخواص الميكانيكية (قوة تحمل الضغط والثد والتحمل) ، كما تم تحديد معامل تهوين (تقليل) الصوت ومقاومة الحريق باسئ للمنتجات محل الدراسة ومقارنة المنتج بالمواصفات الدولية والتجارية للصوف الصخري خاصة المواصفات الأوروبية والأمريكية . أثنارت الدراسة إلى أن المناطق محل الدراسة تحوي درجات مختلفة يمكن توظيفها لإنتاج درجات جودة متفاوتة من الصوف الصخري وقد أوضحت النتائج والدراسات الجيوكيميائية والتمعدنية للبازلت بمنطقة الفيوم امكانية استخدامه لإنتاج درجات فائقة الجودة تتوافق مع المواصفات العالمية المطلوبة. خلصت الورقة البحثية إلى أن صخور البازلت بالمناطق الثناث سالفة الذكر تحوي المواد الخام ذات الخصائص الجيولوجية والجيوكيميائية والتمعدنية التي تتطلب انثاء مزيد من مصانع الصوف الصخري بمصر مما سيعزز من مفهوم التتمية المستدامة وتوفير المواد البادئة والطاقة على حد سواء، وتقليل الفاقد في العطلية الانتاجية وخفض تكاليف انتاج طن الصوف الصخري في الوقت الحالي وتغذية السوق المحلى وفتح أسواق في القارة الافريقية التي ينقصها هذه المنتجات. 